\title{
An English Learning: Rural Students Beliefs
}

\section{Mulia $^{1 *}$, Amiruddin', Abdul Manan ${ }^{3,}$ Khairisman $^{4}$ 1,2,3,4 Ar-Raniry Islamic University, Banda Aceh Indonesia}

\section{A R T I C L E I N F O \\ Article history: \\ Received January 31, 2021 \\ Revised February 02, 2021 \\ Accepted April 17, 2021 \\ Available online May 25, 2021}

\section{Kata Kunci:}

Pembelajaran Bahasa Inggris, Siswa Pedesaan, Keyakinan

\section{Keywords:}

English Learning, Rural Students, Beliefs

DOI:

http://dx.doi.org/10.23887/jpbi.v9 i1.31669

\section{A B S T R A C T}

This study departs from the researcher's experience as a volunteer teacher in a school where students face obstacles in learning English due to a lack of motivation and supporting facilities that impact their English performance. Therefore, the purpose of this study is to analyze beliefs in learning English. This study uses a quantitative method with a survey design using Horwitz's Beliefs About Language Learning Inventory questionnaire as a research instrument. The population in this study found 136 students. The instrument used to collect data is a questionnaire. The technique used to analyze the research data is qualitative and quantitative analysis. The findings show that students support various beliefs about learning English. The most common beliefs held by students are motivation and expectations. Students have reasonable confidence in motivation and hope $(72.35 \%)$ because they have a better education, and a future career can be achieved through good English skills. It can be said that students have good motivation to learn English because they think it will be helpful for their dream job in the future.

This is an open access article under the CC BY-SA license. Copyright (C) 2021 by Author. Published by Universitas Pendidikan Ganesha.

\begin{abstract}
A B S T R A K kurangnya motivasi dan fasilitas pendukung yang kemudian berdampak pada kinerja bahasa Inggris mereka. Oleh karena itu, tujuan penelitian ini yaitu menganalisis kepercayaan dalam belajar bahasa Inggris. Penelitian ini metode kuantitatif dengan desain survei dengan menggunaker penelitian. Populasi pada penelitian ini berjumlah 136 siswa. Instrument yang digunakan untuk mengumpulkan data yaitu kuesioner. Teknik yang digunakan untuk menganalisis data penelitian yaitu analisis kualitatif dan kuantitatif. Temuan menunjukkan bahwa siswa mendukung berbagai keyakinan tentang pembelajaran bahasa Inggris. Keyakinan yang paling umum dipegang oleh siswa adalah motivasi an. Siswa memiliki keyakinan yang baik dalam motivasi dan harap di masa depan dapat dicapai melalui kemampuan bahasa Inggris yang baik. Dapat disimpulkan bahwa siswa memiliki motivasi yang baik dalam belajar bahasa Inggris karena mereka menganggapnya akan berguna untuk pekerjaan impian mereka di masa depan.
\end{abstract}

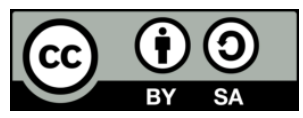

\section{INTRODUCTION}

Starting in the middle 1980s, learners' beliefs have become the attention of researchers and have become a hot topic to discuss. The efforts made by researchers to show the importance of beliefs in language learning have begun since the assumption that success in language learning depends less on materials or linguistic analysis, but it relies more on what the individuals have in mind about the language itself. Language educators have realized that learners hold some complex beliefs about learning a language such as beliefs about the best way to learn a language and beliefs about the pros and cons of the language tasks (Szöcs, 2017).

Innumerable studies have been carried out to discover the differences between successful language learners and unsuccessful ones (Cekaite, 2017; Mahalingam \& Yunus, 2017). Since the 1970s, language researchers continue the search for good language learners in two areas. The first interest is in language learners' strategies concerning any action taken by the learners to make learning easier, faster, more effective, and more enjoyable (Ang et al., 2017). The second one is that language learners' beliefs related to any preconceived ideas, views, and opinions that they have about language learning (Al-Malki \& Zahid Javid, 2018).

Beliefs are the base concept that individuals have in defining and understanding the world and themselves (Kivunja \& Kuyini, 2017). They are developed whether consciously or unconsciously by various variables such as learners' cultural background (Pourkalhor \& Esfandiari, 2017; Sharif Matthews \& López, 2019), pedagogical situation (He et al., 2017; Mellom et al., 2018), or previous learning experiences (Fryer et al., 
2019; Mitchell et al., 2017). Moreover, researchers believe that language learners come to the classroom bringing their various beliefs about the language itself (Kalaja et al., 2017; Mellom et al., 2018).

Furthermore, learners' beliefs will affect not only their attempts in learning a language but also their methods and strategies used to achieve the proficiency level of the target language. For example, positive beliefs ease learners to resolve issues and keep their motivation, while negative beliefs tend to diminish their motivation (LaForce et al., 2017). Besides, to provide more evidence that beliefs have a major influence on learners' achievement, many studies report that learners who hold positive beliefs about language learning acquire higher proficiency levels compare to those who do not have (Jaekel et al., 2017; Saito et al., 2018). Moreover, many studies prove that beliefs can influence the learning process which may either help or hinder the success of language acquisition itself (Huang et al., 2020; Jennifer \& Park, 2015; Mueller \& Dunlosky, 2017; O'Keefe et al., 2021). For example, if studying a language is considered important or interesting, students will reveal a higher degree of motivation and thus their mastery of the language will increase (Lasagabaster, 2017).

In Indonesia, the differences between schools in rural and urban areas have become a major problem in the educational realm regarding facilities and teachers. Schools in a city or urban area have sufficient facilities for English learning and have more competent teachers than schools in a rural area. Therefore, students in the urban area learn English comfortably supported by good facilities for English learning and skilled teachers. In contrast, students in a rural area must deal with an inferior learning environment due to limited facilities for English learning and a lack of English teachers (Rahmat \& Akbar, 2019). In this inferior environment, students might have formed some mistaken beliefs about English learning (Aini, 2020; Anam \& Stracke, 2020; Khotimah et al., 2019; Setianengsih et al., 2017). For instance, they might believe that learning English is all about grammar and vocabulary as they always deal with in their classroom (Sulistiyo, 2018). Their cultural backgrounds such as gender and age also influence the beliefs, they hold such as when they believe males are better at English learning than females or vice versa (Zein et al., 2020).

To be more specific, based on the researcher experienced as a voluntary teacher in the Teunom district of Aceh Jaya Regency, students have been facing barriers in learning English as they lack motivation and supporting facilities such as teacher and language laboratory which then impact their English performance. Also, it is proved by their unwillingness to communicate in English even in the classroom. It is the opposite to students in urban areas such as in Banda Aceh where students are quite comfortable speaking English and good in any other English skills such as writing and reading. Therefore, the researchers were motivated to conduct this research to find out their holding beliefs about English learning. It is vital since beliefs are the primary aspect of learning, which then can shape students' motivation, self-efficacy, and strategies chosen in learning English which then can lead them to be good language learners and autonomous learners as suggested by Torres and Alieto (2019). Moreover, this research focuses on finding rural students' beliefs about English learning at three remote junior high schools located in the Teunom district of Aceh Jaya regency. Therefore, this study aims to analyze information about confidence in learning English.

\section{METHOD}

The study was conducted in three different junior high schools in the Teunom district of Aceh Jaya regency. As a result, 136 students were given a questionnaire during the class session. The beliefs about Language Learning Inventory (BALLI) questionnaire developed by Horwitz (1988) was used in this research. The original BALLI is on a 5-point Likert scale consisting of 34 items. The BALLI is used as an instrument to identify students' language learning beliefs in five areas: foreign language aptitude, the difficulty of language learning, the nature of language learning, learning and communication strategies, and motivation and expectation.

In this study, however, the BALLI was modified and translated into Indonesian to get accurate information about the students' beliefs in language learning. In addition, the number of BALLI items was also modified to be 25 items, in which each category had 5 items. The data elicited from students' responses to each item of the BALLI was checked for validation carefully. Then, the data were categorized to be inputted into the computer and analyzed quantitatively using Microsoft Office Excel 2013.

\section{RESULT AND DISCUSSION}

\section{Result}

The questions about the characteristics of good English language learners show interesting results. The students overwhelmingly agreed $(83.09 \%)$ with the statement that children are better in English learning than adults. In contrast, students reported their disagreement with the statement "women are better than men at 
learning English" with up to $65.44 \%$. Similarly, $69.85 \%$ of students felt disagree with the notion of good students in science are not good at learning English.

Table 1. Beliefs about Foreign Language Aptitude

\begin{tabular}{|c|c|c|c|c|}
\hline Item & Statement & $\begin{array}{c}\text { Agree } \\
(\%)\end{array}$ & $\begin{array}{c}\text { Undecided } \\
(\%)\end{array}$ & $\begin{array}{c}\text { Disagree } \\
(\%)\end{array}$ \\
\hline 1 & $\begin{array}{l}\text { It is easier for children }(12-18 \text { yrs.) than adults (18 } \\
-21 \text { yrs.) to learn English. }\end{array}$ & 83.09 & 11.03 & 5.88 \\
\hline 2 & $\begin{array}{l}\text { Some people have a special ability for learning } \\
\text { English. }\end{array}$ & 75.00 & 16.18 & 8.82 \\
\hline 3 & I have aptitude for learning English. & 30.15 & 48.53 & 21.32 \\
\hline 4 & $\begin{array}{l}\text { People who are good at mathematics or science are } \\
\text { not good at learning English. }\end{array}$ & 11.76 & 18.38 & 69.85 \\
\hline 5 & $\begin{array}{c}\text { Women are better than men at learning English. } \\
\text { Total }\end{array}$ & $\begin{array}{l}17.65 \\
43.53\end{array}$ & $\begin{array}{l}16.91 \\
22.21\end{array}$ & $\begin{array}{l}65.44 \\
34.26\end{array}$ \\
\hline
\end{tabular}

Regarding the special ability needed in learning English, $75 \%$ of students agreed with the statement "some people have a special ability for learning English". When it comes to their aptitude for learning English, the result showed a slight difference between those who agreed and disagreed, only $30.15 \%$ of students agreed to the statement "I have an aptitude for learning English" compared to $21.32 \%$ of those who disagreed.

Most students surveyed believed that English is in a medium level of difficulty. Regarding the time required for learning English, surprisingly, the students disagreed with item number 8. It indicates that if someone wants to speak English fluently, s/he must spend more than one hour a day learning English. However, they were very optimistic in their prognosis to their fluency as language learners. It is proved by their responses with up to $53.68 \%$ who agreed with the idea of "I believe that I will ultimately learn to speak English very well".

Focusing on the difficulty of particular English skills, most students felt that speaking English is easier than understanding it were $55.15 \%$ of them accepted the notion "it is easier to speak than understand English". Similarly, they also came to an agreement that reading and writing English are easier than speaking and understand it (47.79\%). In another word, most of the students believed that understanding English spoken is the most difficult compared to other skills such as reading and writing.

Table 2. Beliefs about the Nature of Language Learning

\begin{tabular}{lllll}
\hline Item & \multicolumn{1}{c}{ Statement } & $\begin{array}{c}\text { Agree } \\
(\mathbf{\%})\end{array}$ & \multicolumn{1}{c}{$\begin{array}{c}\text { Undecided } \\
(\mathbf{\%})\end{array}$} & $\begin{array}{c}\text { Disagree } \\
(\mathbf{\%})\end{array}$ \\
\hline 11 & $\begin{array}{l}\text { It is best to learn English in an English-speaking } \\
\text { country. }\end{array}$ & 44.12 & 18.38 & 37.50 \\
12 & $\begin{array}{l}\text { The most important part of learning English is } \\
\text { learning vocabulary words. }\end{array}$ & 76.47 & 16.91 & 6.62 \\
13 & $\begin{array}{l}\text { The most important part of learning English is } \\
\text { learning grammar. }\end{array}$ & 75.74 & 17.65 & 6.62 \\
14 & $\begin{array}{l}\text { Learning English is different than learning other } \\
\text { academic subjects. }\end{array}$ & 69.12 & 25.00 & 5.88 \\
15 & $\begin{array}{l}\text { The most important part of learning English is } \\
\text { learning how to translate from my native language. } \\
\text { Total }\end{array}$ & 60.29 & 25.74 & 13.97 \\
\hline
\end{tabular}

The idea of learning English is better in English-speaking country had slightly different in response, where $44.12 \%$ of student felt that it is better to learn English in English-speaking country in comparison to $37.50 \%$ students those who felt disagree.

Regarding the language learning task, it shows that the respondents of this study agreed with the statement that learning English is a matter of translating from their native language, learning grammar, and learning vocabulary. The reports show that $76.47 \%$ and $75.74 \%$ of respondents believed that learning vocabulary and grammar is very important. In addition, $60.29 \%$ of students felt that learning English is about how to translate from their native language. 
When it comes to the question about whether learning English is different than learning other academic subjects, $69.12 \%$ of surveyed students put their agreement to the item "learning English is different than learning other academic subjects".

Table 3. Beliefs about Learning and Communication Strategies

\begin{tabular}{|c|c|c|c|c|}
\hline Item & Statement & $\begin{array}{c}\text { Agree } \\
(\%) \\
\end{array}$ & $\begin{array}{c}\text { Undecided } \\
(\%)\end{array}$ & $\begin{array}{c}\text { Disagree } \\
(\%)\end{array}$ \\
\hline 16 & It is important to repeat and practice a lot. & 87.50 & 9.56 & 2.94 \\
\hline 17 & $\begin{array}{l}\text { It is important to practice with tape recorder, } \\
\text { smartphone, or computer. }\end{array}$ & 55.88 & 27.94 & 16.18 \\
\hline 18 & I feel timid speaking English with other people. & 77.94 & 14.71 & 7.35 \\
\hline 19 & $\begin{array}{l}\text { You shouldn't say anything in English until you can } \\
\text { say it correctly. }\end{array}$ & 27.94 & 24.26 & 47.79 \\
\hline \multirow[t]{2}{*}{20} & $\begin{array}{l}\text { It's okay to guess if you don't know a word in } \\
\text { English. }\end{array}$ & 55.15 & 25.74 & 19.12 \\
\hline & Total & 60.88 & 20.44 & 18.68 \\
\hline
\end{tabular}

Referring to the given responses, traditional learning strategies are still endorsed by the students in this study which $87.50 \%$ of them believed that repeating and practicing a lot is very important. Moreover, students of this study also agreed with the statement "it is important to practice with a tape recorder, smartphone or computer" with $55.88 \%$ of responses. Similarly, the students also agreed (55.15\%) with the statement "it is okay to guess if you don't know a word in English".

Concerning communication strategies, many students $(77.94 \%)$ felt shy to speak with other people using the English language. However, many surveyed students disagreed with the statement "you shouldn't say anything in English until you can say it correctly" with up to $47.79 \%$ responses. About the motivation of studying English, the students reported that $80.15 \%$ of them felt that it is very important because people in their country consider English is an important language to be learned. Similarly, almost half of the surveyed students $(48.53 \%)$ believe that by learning English they would have a chance to know native speakers of English better. Interestingly, almost all the students overwhelmingly were motivated in learning to speak English well with the responses up to $94.12 \%$.

Focusing on students' expectations of learning English, $64.71 \%$ of them looked forward to having friends from English-speaking countries. In addition, most students believed that they would have a bright future regarding job opportunities if they were good at English. It was about $74.26 \%$ of them agreed with the statement "If I learn English very well, I will have better opportunities for a good job".

\section{Discussion}

This study found that beliefs about motivation and expectations are the most common beliefs students hold followed by beliefs about the nature of language learning, beliefs about learning and communication strategies, beliefs about foreign language aptitude, and beliefs about the difficulty of language learning beliefs. Motivation and expectation appear to be the most common beliefs possessed by rural junior high schools students in Teunom. This finding comes in line with the finding of earlier research who also found motivation and expectation as the most common beliefs held by the students in their research (O'Keefe et al., 2021; Torres \& Alieto, 2019). In addition, motivation and expectation is the primary factor in language learning and because of that learning should be enjoyable.

In general, the students in this survey are highly motivated in learning to speak English. They rely on their assumption that Indonesian or Acehnese in specific feel that being able to speak English well is quite important. The logical reason for the importance of having English skills is related to better job opportunities in the future. Undeniably, almost all job vacancies in Indonesia put English skill as one of the skills that job applicants must have (Majid et al., 2012; Mohammadi et al., 2020). Also, as a standard medium of communication, good proficiency in English is required to face the challenge of global economic development. Besides, the Indonesian government also put English as a must requirement for higher study (Liu et al., 2021; Masrur et al., 2020).

Furthermore, the high students' motivation in the current study is also influenced by their willingness to interact with English speakers, so that they will get a chance to befriend such English native speakers (Fu et al., 2019; Karaca \& Uysal, 2021). It may also indicate that their interactions with English native speakers will make them easily improve their English, especially in communication skills. The second common belief held by 
students in this study is beliefs about the nature of language learning. The nature of language learning was found as the second common belief held by Korean middle school students (Jennifer \& Park, 2015).

In the current study, most participants believe that grammar and vocabulary are crucial in learning English. It is perhaps derived from their experiences as language learners where they take part in it (Mitchell et al., 2017; Thoyyibah et al., 2019). whereas teachers tend to believe learning a language is more about "focus on forms" than "focus on meanings". Additionally, the teaching strategies employed by a teacher in the classroom are also able to inculcate a thought into students' belief system directly or indirectly (Pourkalhor \& Esfandiari, 2017; Szőcs, 2017). Unsuccessful language learners tend to possess unrealistic beliefs about English learning such as they accept as true that English is difficult and they value translation in English learning as the most important (Kalaja et al., 2017).

In addition to the mistaken beliefs, more than seventy-five percent of students in this study believe that some people are gifted for learning English. Yet, when they are asked whether or not they are good at learning English only thirty percent of them agree that they have language learning ability. Having a slight difference in percentage with the second common mistaken beliefs, beliefs about learning and communication strategies comes as the third common beliefs held by students in this study. The students highly agreed with some aspects of this belief category such as repetition and practice are vital in learning English. Additionally, the findings of this study show that most students feel shy to practice their English with other people. It is, however, contradicts their motivation of learning to speak English well. A rationale reason for this contradiction is the environment, where vernacular still become the most accepted language to communicate even in the school environment. Previous findings studied the beliefs of Korean high school students using the Horwitz inventory questionnaire. In their findings, motivation and expectations were also found to be the most common beliefs (Jennifer \& Park, 2015). As a result of this study, it found that junior high school students in the Teunom district hold good motivation in learning English since they consider it will be useful for their dream job in the future.

\section{CONCLUSION}

Senior high school students in the Teunom district endorsed a variety of beliefs about English learning. They had good beliefs in motivation and expectations (72.35\%) since they were aware of having better education and a job career in the future can be achieved through good English skills. Regarding the way to approach the learning, the students believed that the best way to learn English was through learning its linguistic elements and vocabulary. Also, the students believed that repetition was the best way to learn English. In another word, the students in this survey still preferred to use a conventional way of learning English such as learning grammar, memorizing, and repetition. In addition, some students of the study also held mistaken and complicated beliefs about learning. Also, they had good motivation in learning English, while on the other hand they also felt timid to practice their English that would be an example of complicated beliefs.

\section{REFERENCES}

Aini, S. H. (2020). The Relationship between Students' Beliefs and Willingness to Communicate Among Indonesian Senior High School Students in EFL Classroom. Retain, 8(1), 16-24. https://ejournal.unesa.ac.id/index.php/retain/article/view/31814

Al-Malki, E. A., \& Zahid Javid, C. (2018). Identification of Language Learning Beliefs Among Saudi EFL Learners. SSRN Electronic Journal, 9(4). https://doi.org/10.24093/awej/vol9no4.13

Anam, S., \& Stracke, E. (2020). The role of self-efficacy beliefs in learning English as a foreign language among young Indonesians. TESOL Journal, 11(1). https://doi.org/10.1002/tesj.440

Ang, S., Embi, M. A., \& Yunus, M. M. (2017). Strategies of Successful English Language Learners among Private School Students. Jurnal Pendidikan Humaniora, 5(2), 47-57. https://doi.org/10.17977/um030v5i22017p047

Cekaite, A. (2017). What Makes a Child a Good Language Learner? Interactional Competence, Identity, and Immersion in a Swedish Classroom. Annual Review of Applied Linguistics, 37, 45-61. https://doi.org/10.1017/S0267190517000046

Fryer, L. K., Nakao, K., \& Thompson, A. (2019). Chatbot learning partners: Connecting learning experiences, interest and competence. Computers in Human Behavior, 93, 279-289. https://doi.org/10.1016/j.chb.2018.12.023

Fu, Q.-K., Lin, C.-J., Hwang, G.-J., \& Zhang, L. (2019). Impacts of a mind mapping-based contextual gaming approach on EFL students' writing performance, learning perceptions and generative uses in an English course. Computers \& Education, 137. https://doi.org/10.1016/j.compedu.2019.04.005

He, Y., Lundgren, K., \& Pynes, P. (2017). Impact of short-term study abroad program: Inservice teachers' development of intercultural competence and pedagogical beliefs. Teaching and Teacher Education, 66, 
147-157. https://doi.org/10.1016/j.tate.2017.04.012

Horwitz, E. K. (1988). The Beliefs about Language Learning of Beginning University Foreign Language Students. The Modern Language Journal, 72(3), 283. https://doi.org/10.2307/327506

Huang, F., Sánchez-Prieto, J. C., Teo, T., García-Peñalvo, F. J., Sánchez, E. M. T., \& Zhao, C. (2020). The influence of university students' learning beliefs on their intentions to use mobile technologies in learning: a study in China and Spain. Educational Technology Research and Development, 68(6), 3547-3565. https://doi.org/10.1007/s11423-020-09806-0

Jaekel, N., Schurig, M., Florian, M., \& Ritter, M. (2017). From Early Starters to Late Finishers? A Longitudinal Study of Early Foreign Language Learning in School. Language Learning, 67(3), 631-664. https://doi.org/10.1111/lang.12242

Jennifer, M. Y., \& Park, Y. (2015). Investigating middle school students' beliefs about English language learning in the Korean EFL context. International Journal of Teaching, Education and Language Learning, 2(4), 88-121. http://paper.researchbib.com/view/paper/66087

Kalaja, P., Barcelos, A. M. F., \& Aro, M. (2017). Revisiting Research on L2 Learner Beliefs: Looking Back and Looking Forward. In J. M. Cots \& P. Garrett (Eds.), The Routledge Handbook of Language Awareness (1st ed., pp. 222-237). Routledge.

Karaca, M., \& Uysal, H. H. (2021). The development and validation of an inventory on English writing teacher beliefs. Assessing Writing, 47. https://doi.org/10.1016/j.asw.2020.100507

Khotimah, K., Widiati, U., Mustofa, M., \& Ubaidillah, M. F. (2019). Autonomous English learning: Teachers' and students' perceptions. Indonesian Journal of Applied Linguistics, 9(2). https://doi.org/10.17509/ijal.v9i2.20234

Kivunja, C., \& Kuyini, A. B. (2017). Understanding and Applying Research Paradigms in Educational Contexts. International Journal of Higher Education, 6(5), 26-41. https://www.sciedu.ca/journal/index.php/ijhe/article/view/12169

LaForce, M., Noble, E., \& Blackwell, C. (2017). Problem-Based Learning (PBL) and Student Interest in STEM Careers: The Roles of Motivation and Ability Beliefs. Education Sciences, 7(4), 92. https://doi.org/10.3390/educsci7040092

Lasagabaster, D. (2017). Language Learning Motivation and Language Attitudes in Multilingual Spain From an International Perspective. The Modern Language Journal, 101(3), 583-596. https://doi.org/10.1111/modl.12414

Liu, C., He, J., Ding, C., Fan, X., Hwang, G.-J., \& Zhang, Y. (2021). Self-oriented learning perfectionism and English learning burnout among EFL learners using mobile applications: The mediating roles of English learning anxiety and grit. Learning and Individual Differences, 88. https://doi.org/10.1016/j.lindif.2021.102011

Mahalingam, K., \& Yunus, M. M. (2017). Good Language Learners And Their Strategies: An Insight. Proceedings of the ICECRS, 1 (1). https://doi.org/10.21070/picecrs.v1i1.504

Majid, M. S. Z. B. A., Ali, M. M. B. A., Rahim, A. A. B. A., \& Khamis, N. Y. B. (2012). The Development of Technical English Multimedia Interactive Module to Enhance Student Centered Learning (SCL). Procedia - Social and Behavioral Sciences, 67, 345-348. https://doi.org/10.1016/j.sbspro.2012.11.337

Masrur, I., Irawati, E., \& Sulistyo, G. H. (2020). Integrating Writing Process with Quantum Learning Framework in English Language Teaching. Jurnal Pendidikan: Teori, Penelitian, Dan Pengembangan, 5(3). https://doi.org/10.17977/jptpp.v5i3.13262

Mellom, P. J., Straubhaar, R., Balderas, C., Ariail, M., \& Portes, P. R. (2018). "They come with nothing:” How professional development in a culturally responsive pedagogy shapes teacher attitudes towards Latino/a English language learners. Teaching and Teacher Education, 71, 98-107. https://doi.org/10.1016/j.tate.2017.12.013

Mitchell, C., Del Fabbro, L., \& Shaw, J. (2017). The acculturation, language and learning experiences of international nursing students: Implications for nursing education. Nurse Education Today, 56, 16-22. https://doi.org/10.1016/j.nedt.2017.05.019

Mohammadi, M., Moenikia, M., \& Zahed-Babelan, A. (2020). The role of advance organizer on English language learning as a second language. Procedia - Social and Behavioral Sciences, 2(2). https://doi.org/10.1016/j.sbspro.2010.03.747

Mueller, M. L., \& Dunlosky, J. (2017). How beliefs can impact judgments of learning: Evaluating analytic processing theory with beliefs about fluency. Journal of Memory and Language, 93, 245-258. https://doi.org/10.1016/j.jml.2016.10.008

O'Keefe, P. A., Lee, H. Y., \& Chen, P. (2021). Changing Students' Beliefs About Learning Can Unveil Their Potential. Policy Insights from the Behavioral and Brain Sciences, 8(1), 84-91. https://doi.org/10.1177/2372732220984173 
Pourkalhor, O., \& Esfandiari, N. (2017). Culture in Language Learning: Background, Issues and Implications. International Journal of English Language \& Translation Studies, 5(1), 23-32.

Rahmat, A., \& Akbar, M. (2019). A Comparative Analysis of English Learning Motivation between the Rural and Urban Students. Metathesis: Journal of English Language, Literature, and Teaching, 3(2), 158. https://doi.org/10.31002/metathesis.v3i2.1740

Saito, K., Dewaele, J.-M., Abe, M., \& In'nami, Y. (2018). Motivation, Emotion, Learning Experience, and Second Language Comprehensibility Development in Classroom Settings: A Cross-Sectional and Longitudinal Study. Language Learning, 68(3), 709-743. https://doi.org/10.1111/lang.12297

Setianengsih, E., Salam, U., \& Arifin, Z. (2017). Attitude Towards English Language Learning (a Survey on the Rural Students of Sman 2 Paloh). Jurnal Pendidikan Dan Pembelajaran Untan, 6(11), 1-11.

Sharif Matthews, J., \& López, F. (2019). Speaking their language: The role of cultural content integration and heritage language for academic achievement among Latino children. Contemporary Educational Psychology, 57, 72-86. https://doi.org/10.1016/j.cedpsych.2018.01.005

Sulistiyo, U. (2018). Factors Affecting English Language Learning in English as a Foreign Language (EFL) Context: A Literature Review Study. Indonesian Journal Of Educational Research, 3(1), 20-24. https://doi.org/10.30631/ijer.v3i1.54

Szöcs, K. (2017). Teachers' and learners' beliefs about language learning autonomy and its implications in the classroom: A mixed method study. Apples - Journal of Applied Language Studies, 11(2), 125-145. https://doi.org/10.17011/apples/urn.201708233542

Thoyyibah, N., Hartono, R., \& Bharati, D. A. L. (2019). The Implementation of Character Education in the English Teaching Learning Using 2013 Curriculum. English Education Journal, 9(2), 254-266. https://doi.org/10.15294/eej.v9i2.30058

Torres, J. M., \& Alieto, E. O. (2019). English Learning Motivation and Self-Efficacy of Filipino Senior High School Students. Asian EFL Journal, 22(1), 51-72.

Zein, S., Sukyadi, D., Hamied, F. A., \& Lengkanawati, N. S. (2020). English language education in Indonesia: A review of research (2011-2019). Language Teaching, 53(4), 491-523. https://doi.org/10.1017/S0261444820000208 